\title{
PAUSE AND SLIP OF THE TONGUE ON STAND UP COMEDY SHOW IN INDONESIA
}

\author{
Muhammad Asyura \\ Indonesia University of Education, Indonesia, muhammadasyuramuhammad@gmail.com
}

\begin{abstract}
Language and mind are connecting each other with mental process to decide ideas to what will be delivered in spoken language. Some contexts, including spoken humour, does not seldom occur errors in delivering. This case occurs to comica in creating humorous ideas delivering in stand-up comedy. This purpose of this research is to describe the pause and slip of the tongue that happens on stand-up comedy show in Indonesia. The research is the study psycholinguistics. Language and mind related to mental processes in which comica forms a humour speech. Data was analysed in form of 20 pieces of stand-up comedy videos on television that is downloaded via YouTube. The methods of collecting data are done by using listening and recording in the observation. The methods of data analysis are done by transcribing the data which have been obtained or recorded into the data card orthographic, whereas the data analysis was presented in the form of description by describing the forms and causes of pause and slip of the tongue happened by comica in stand-up comedy show. The results of this research are the discovery of two kinds pauses, namely pause because of respiratory and the speaker experiencing doubts. The slip of the tongue can occur due to the fact that the comica spoke hastily and did not concentrate. The slip of the tongue units are happened the in phonetics, syllables, and words. The occurrence of pause and slip of the tongue by comica are caused by nervousness, hesitance, fear, and they are too careful in presenting the humour case due to the need for time management and the competitive situation.
\end{abstract}

Keyword: pause, slip of the tongue, phsycholinguistics

\section{INTRODUCTION}

Speech act is a way people to communicate. In speech act, sometime people have error. Un-fluency and error cause mistake in speech act. Periodically, they can produce discourse that is inappropriate between what they say and what they mean. To use words being opportune, sometimes speaker stopped for a while. It is called pause phenomena. While speaker happen error (inappropriate between what that say and what mean) at conversation, it is called the slip of tongue phenomena.

According to Jaeger (2005:2) slips of the tongue is an error in discourse production planning; namely while speaker wants to announce many words, phrases, or sentences, and while the planning process is happening something wrong so that the production is not appropriate with the planning. Pause and slip of 
the tongue strop can happen on each speaker in various situations. Pause is someone's un-fluency in speech act, meanwhile slip of the tongue constitutes in speech act.

Pause and slip of the tongue which happen to each speaker can be done deliberately or not. But then, on pause's case tends often to occur because of not on purpose factor. Ordinary slip of the tongue which is announced in deliberate usually have particular intention, which is deliberate to create humour.

Theory utilizing for study of pause and slip of the tongue is psycholinguistics. This study constitutes knowledge and investigates how to arrange speech act and writing; how to keep and utilize lexicon; and how can experience in getting error of language (Field, 2004:9). This research pulls for writer because phenomenon on pause and slip of the tongue become common in social life, but it often do not realize causes. Lingual's population in observation is all discourse that contains pause and slip of the tongue in stand-up comedy show's projection that is downloaded via YouTube. Population in this observation is still very large. So, taking of sample is based on data representatively and can represent the other data. Therefore, observational data was taken randomly based on language unit aught on pause and slip of the tongue. Based on this consideration, data used in this study is in form of 20 videos on Stand Up Comedy Academy (SUCA) on private channel in Indonesia, such as Indosiar via YouTube. Methods of collecting data were done by using listening and recording for such observation. Methods of data analysis done by transcribing the data have been obtained or recorded into the data card orthographic, whereas the data analysis presented in the form of description by describing the forms and causes of pause and slip of the tongue happens by comica in SUCA.

\section{PSYCHOLINGUISTIC ASPECS ON STAND UP COMEDY SHOW}

Research about pause and slip of the tongue comes in pshyscolinguistic's scope. According to Darwowidjojo (2008:7), psycholinguistics is a knowledge that study about human mental processes for language. This study has four main topics, which are comprehension, production, basis for biology and neurology which make people can converse and language acquisition.

As one is explained in advance, conversing people tend to experience to get dis-function of language with various contexts including stress and nervousness while conversation. It also happens on humour context. Modern jest that being liked by Indonesia society is so medley e.g. jest one script that at impersonate a lot of figure and also stand-up comedy which announced by one figure. Stand-up comedy as arena of talent search was efflorescing at the one Indonesia amongst those at Indosiar. This event is Stand-up Comedy Academy (SUCA). The event presents best Indonesian comica as mentor. SUCA was evident its ability in bear comedy star. This event has entered second one season present one every Monday until Thursday. Despite of it, this paper discusses disfunction of language which is pause and slip of the tongue in SUCA'S projection that announced by comica.

\subsection{Pause on Stand-up Comedy Show}

According to Darwowidjojo (2008:142), good speech act is statement that allegedly been strung up neatly, uttered in one thread that doesn't be hung up, for example, there is a pause, it occurs on constituents that really enables for pause. Moreover, the intonation is a unity start at first until the end. But then, someone can get to say at ease at all, there is pause in utterance sound. Get bearing with pause, Darwowidjojo (2008:144) says that there is reason sort while someone silences in gets to say. First, person who is in silence since overshoot to begin with utterance, but it actually was ready to exhaustive that sentence. Second, it is caused by forgetting the needful words. Third, it is on the quivive in choosing word.

Pause doesn't happen at bungling place. According to Clark \& Clark (1977:267), there is its places pause which is:

\section{a. grammatical juncture}

Grammatical juncture is pause's place to plot framework and also first constituent of sentence who will be announced. Pause as it long time tend and often. Pause as it is logical because this pause was used too for breathes. Thus, actually pause this is not included that dubiety type. But pause is doubt just has no clause betwixt, but in clause (Aitchison, 1998:239).

\section{b. the other constituent boundses}

On this bounds person that pause can also because at here person plots details of of next main constituent, e.g., nomina's phrase, verba's phrase, and pronomina's phrase which would be convenient for sentence framework already been formed. Planning as it of course it require time and in consequence pause emerges. senyapan here by and large as pause is filled. 
c. before first head word on constituents

After sekeletal molded, therefore constituent shall be filled by word. On English, nomina's phrase that began by the can arise pause because speaker can just have overshoot issue to say it but she then has to look for nomina or other word would be convenient. Thus, therefore available pause between the with next head words: the // man ... (bastard, bloke?). Generally pause on construction as it as pause silent. On language whereabouts specifiernya lies after head word (that man, not it person), it describes ruling it is inoperative because preceding beginning people with its head word, they new keeps on it with specifier that.

English has various tricks to fill pause and this filler have meaning each for example (Clark \& Clark, 1977:268).

$\mathrm{Oh}=$ for referen's elect

$A h=$ for memory fruitfulness

Well $=$ for resemblance to say

Say $=$ for example

So also word as that is, or rather, I mean, and well has particular meaning.

That is $=$ to edit referen

example: He hit Mary, that is, Bill did with a pan.

Or rather $=$ to edit nuance

example: I am trying to lease, or rather, sublease my apartment.

I mean = to edit fault

example: On His Head, I mean, his hand, we saw some money.

Well $=$ to edit claim

example: I' II be done soon, well, in ten minutes.

Bahasa Indonesia also has same apparatus. Word as anu, apa itu, siapa itu often areused as pause's filler. Someone also frequently fills this pause with giving sounds as em, eh,and $u h$ that just a constitute sheer filler or it is also for to be able to cautious while saying in order not to evoke wrong impact. Example:

What is that

... anu ... (context: something's name that yesterday comes here)

Who is that

... siapa itu ... (context: someone's name that yesterday comes here)

I want to look for

... apa itu ... (context: vermicide)

Example:

According to President .... eh .... this problem has .... eh .... made to be basic .... This constitutes ... eh .... Problem that ... em .... Need observed that ... eh ....

Commonly, pause comprises of two types which are pause in silent and pause in filled. On SUCA'S projection, filled pause often occurs more. It is caused by comica is charged to be capable to pass on humour material with relative laconic time. This charge makes comica shall think quick to prevent nervousness and chooses lexicon in point to reveal humour discourse. The following table will describe data and example of pause on comica SUCA: 
IJASOS- International E-Journal of Advances in Social Sciences, Vol. III, Issue 7, April 2017

\begin{tabular}{|c|c|c|c|c|}
\hline No & Comica & Discourse & $\begin{array}{c}\text { Discourse } \\
\text { Context }\end{array}$ & $\begin{array}{l}\text { Pause } \\
\text { Form }\end{array}$ \\
\hline 1 & Aciresti & $\begin{array}{l}\text { there are seven pause's times: } \\
\text {... akhirnya Gua ada di } 16 \text { besar, senang } \\
\text { banget ya, eee, dan Gua semakin berharap } \\
\text { banyak yang kenal Gua, kenal Gua, soalnya } \\
\text { kemaren eee. Ada yang, apa, negor Gua... }\end{array}$ & $\begin{array}{l}\text { Session in } \\
\text { introducing self }\end{array}$ & $\begin{array}{l}\text { Filled } \\
\text { Pause }\end{array}$ \\
\hline 2 & $\begin{array}{l}\text { Benny } \\
\text { Siregar }\end{array}$ & $\begin{array}{l}\text { there are two pause's times: } \\
\text { (1) } \\
\text {....biasa di panggil Benny. Eee ngomong- } \\
\text { ngomong disini ada.... } \\
\text { (2) } \\
\text {...Cemen aja ngak bisa eeee tapi eee terima } \\
\text { kasih ketawanya mas Yudi...eee sebelum } \\
\text { lanjut saya akan cerita... }\end{array}$ & $\begin{array}{l}\text { (1) Session in } \\
\text { introducing self } \\
\text { (2) Thinking to } \\
\text { draw out humor } \\
\text { discourse }\end{array}$ & $\begin{array}{l}\text { Filled } \\
\text { Pause }\end{array}$ \\
\hline 3 & Musdalifa & $\begin{array}{l}\text { there are three pause's times: } \\
\text { (1) } \\
\text { Selain... hehe... selain dangdut saya juga } \\
\text { pecita smack down... } \\
\text { (2) } \\
\text {....Jadi, apa, saking pelitnya itu was eee } \\
\text { saking pelitnya setiap teman saya... } \\
\text { (3) } \\
\text {...dan paling saya benci itu disinetron eh apa } \\
\text { adegan orang bahagia... } \\
\text { (4) } \\
\text {...cuma ada disinetron, apa, pengemis yang } \\
\text { muka eee masak ada pengemis... }\end{array}$ & $\begin{array}{l}\text { (1)Session } \\
\text { passes on humor } \\
\text { discourse. } \\
\text { (2), (3) and (4) } \\
\text { Stop few seconds } \\
\text { while demulcent } \\
\text { razzing. } \\
\text { It happens since } \\
\text { comica is false to } \\
\text { pass the } \\
\text { introductions of } \\
\text { humor on. }\end{array}$ & $\begin{array}{l}\text { Silent } \\
\text { Pause }\end{array}$ \\
\hline 4 & Cemen & $\begin{array}{l}\text { there is one pause's times: } \\
\text {...bukan masalah apa apa.. bukan masalah } \\
\text { gitu itu gitu...emang dikhidupan nyata } \\
\text { ngomongnya kyak gitu juga.... }\end{array}$ & $\begin{array}{l}\text { Session passes } \\
\text { on humor } \\
\text { discourse. Stop } \\
\text { passes on humor } \\
\text { discourse with } \\
\text { looped word. }\end{array}$ & $\begin{array}{l}\text { Filled } \\
\text { Pause }\end{array}$ \\
\hline 5 & $\begin{array}{l}\text { Musdalifa } \\
\text { and } \\
\text { Cemen }\end{array}$ & $\begin{array}{l}\text { there are three pause's times: } \\
\text { 1. Musdalifah speech } \\
\text {...sudah bercita-cita jadi biduan. Tapi, ee el } \\
\text { bercita-cita jadi biduan tapi apa ya, susah gitu } \\
\text { karena... } \\
\text {...dan gara-gara itu saya berpikir, apa ya, } \\
\text { berberpikiran jadi biduan, saya sekarang } \\
\text { berpikiran mau jadi polwan... } \\
\text { 2. Cemen speech } \\
\text {...tapi nih yah kalau meee lihat musik } \\
\text { dangdut... }\end{array}$ & $\begin{array}{l}\text { Session matches } \\
\text { against humor } \\
\text { between } \\
\text { Musdalifah and } \\
\text { Cemen }\end{array}$ & $\begin{array}{l}\text { Filled } \\
\text { Pause }\end{array}$ \\
\hline
\end{tabular}

There is unique case on pause on SUCA's phenomena. It occurs silent pause at each discourse interval. It is caused by Comica being deliberate to be pause in few seconds to wait audiences bursting out and then 
continue his/her humour discourse to get next attention. It happens at each projection SUCA and constitutes strategy or rhetorical comica that his/her humour content becomes comic.

\section{a. Slip of the Tongue on Stand-up Comedy Show}

Gleason and Ratner (1998:312) stated that slip of the tongue can happen deeply in normal talk. It means that in a talk that happens normally can occur in some words or sentences which don't lap over as it must be. Error in converses can be identified deeply in ten forms, they are (1) consonantal anticipation, (2) perseveration consonants, (3) changing consonants and cluster division,(4) consonantal disappearances, (5) anticipations and insertion of consonant, (6) consonant classification of division, (7) changing vowel, (8) vowel's anticipations, (9) vowel preservation,(10) agglomerate changed consonantal cannikins consonantal, and (11) changing cluster consonant.

Slip of the tongue happens in many linguistics levels. It can be described in a few units. There are three units of linguistics levels; they are phonetic segment error, syllable error, and word error.

Generally, there are two slip of the tongue's kinds; they are selection error and assembles error. Selection error becomes to be divided in to some types, they are:

\section{a. Error in semantic selection (Freudian Slips)}

This happens on semantic level. There is different intended concept between what he/she means and what he/she utters so that occurs the error of semantic facet. Example:

Left... left... To left... ups sorry, I mean right...

On example, utterance discourse by $A$ to $B$. They go with riding car, $A$ is as driver and $B$ is behind $A$ as indicator of roads. In memory racks brains $B$ has words 'right' and 'left' which have similar semantic fields with. At the moment, B wants to say that to wend place that is looked for ought to veers to right, but while it is announced as left. Hearing the speech, A even direct turns to the left, but B spontaneously screams that veers it to be left. After $A$ answers that she turns to the left, $B$ just realizes that what it is in his brain and what he has announced are different.

\section{b. Malaproprisme}

This kind of error usually aims in order to make the speaker appears intellect and good looking, but actually false.

\section{c. Blends}

This error happens if a person is in headlong so that she take one or a half syllable of first word and one or a half syllable more of second word and then both of the forms was combined to be one word.

In contrast to selection error, assembling error form assembles to happen since words that are chosen are right but it becomes incorrect assembling. This error most subdivides deep some types which are:

\section{a. Transposition}

This error form is effect by transposition, it means to move word or sound from a position to the other position.

\section{b. Anticipation}

Speaker will anticipate its appearance of a sound, then the sound is voiced as replacement instead of the sound that should be.

\section{c. Perseveration}

This error is sometimes also called as repetition, which is opposite of anticipation. If on error's anticipation happens to show at first, on Perseverations error happens on dorsal word.

In line with research by Gary S. Dell and Jill A. Warkerot (2005) said that only are speech errors profoundly important to theories of language production, but also, as we have seen, error patterns suggest usefulavenues of exploration in perception and acquisition, in short, in all of psycholinguistics. Theory-based that, slip of the tongue on SUCA's they can be described and are classified as follows: 
IJASOS- International E-Journal of Advances in Social Sciences, Vol. III, Issue 7, April 2017

\begin{tabular}{|c|c|c|c|c|}
\hline No & Comica & Discourse & Discourse Context & Slip of the Tongue Form \\
\hline 1 & $\begin{array}{l}\text { Yudha } \\
\text { Keling }\end{array}$ & $\begin{array}{l}\text { There are three } \\
\text { slips of the tongue: } \\
\text { (1) } \\
\text {....hari ini gue } \\
\text { senang banget } \\
\text { nampil disni nampil } \\
\text { di sini. Kemarin di } \\
\text { stand up academy } \\
\text { itu gue nam masuk } \\
\text { empat besar... } \\
\text { (2) } \\
\text {...dan kalau dapet } \\
\text { dan gua } \\
\text { membayangin } \\
\text { dapet hadiah jutaan } \\
\text { rupiah itu gue kan } \\
\text { berarati jadi orang } \\
\text { kaya.... }\end{array}$ & $\begin{array}{l}\text { (1) } \\
\text { There is error over on } \\
\text { phonology level which } \\
\text { is called first word } \\
\text { disni that must be di } \\
\text { sini } \\
\text { (2) } \\
\text { There is error over on } \\
\text { level of words since } \\
\text { false in choosing to } \\
\text { say to reveal intention. }\end{array}$ & $\begin{array}{l}\text { (1) } \\
\text { This error happens on phonetic } \\
\text { segment error which is word } \\
\text { disni ought to been called } \\
\text { disini. This is anticipation error } \\
\text { type. } \\
\text { (2) } \\
\text { The error happens on word } \\
\text { segment error. Speaker ought } \\
\text { to say word or phrase dapet } \\
\text { hadiah but he says kalau } \\
\text { dapet instead. This is } \\
\text { anticipation error type. } \\
\text { Error happening is realised by } \\
\text { speaker so that it is done by } \\
\text { statement's repetition. }\end{array}$ \\
\hline 2 & Falah & $\begin{array}{l}\text { There are four slips } \\
\text { of the tongue: } \\
\text { (1) } \\
\text {...Ini dek saya lagi } \\
\text { masak bubur zoom } \\
\text { zoom... } \\
\text { (2) } \\
\text {...kayak teman gue } \\
\text { kan masukok } \\
\text { masuk ke lab } \\
\text { komputer } \\
\text { sepatunnya masih } \\
\text { dipake... } \\
\text { (3) } \\
\text {..tapi pas SMA } \\
\text { saya tuh puee } \\
\text { mulai punya pacar } \\
\text { gitu... } \\
\text { (4) } \\
\text {...tapi saya bangga } \\
\text { pacaran sama dia } \\
\text { sama see sama } \\
\text { bangga saya sama } \\
\text { adik saya... }\end{array}$ & $\begin{array}{l}\text { (1) } \\
\text { There are glosses over } \\
\text { from diction or word. It } \\
\text { supposed to utter sum } \\
\text { sum, in fact, it is } \\
\text { uttered zoom zoom. It } \\
\text { intentionally give } \\
\text { humor effect. } \\
\text { (2) } \\
\text { There is error over on } \\
\text { phonology level which } \\
\text { is called word } \\
\text { masukok, it ought to } \\
\text { utter masuk ke } \\
\text { (3) } \\
\text { There are glosses over } \\
\text { from diction or word. } \\
\text { This fault occurs } \\
\text { woolly because it has } \\
\text { no meaning and clear } \\
\text { context } \\
\text { (4) } \\
\text { There is error over on } \\
\text { phonology level which } \\
\text { is called word see } \\
\text { sama, it supposed to } \\
\text { be sesama }\end{array}$ & $\begin{array}{l}\text { (1) } \\
\text { The error is happening on word } \\
\text { segment error. Speaker ought } \\
\text { to say word sum sum but one is } \\
\text { named is zoom zoom (english } \\
\text { word). This is melaporisme } \\
\text { error type. } \\
\text { (2) } \\
\text { The error's happening on } \\
\text { phonology segment error. } \\
\text { Speaker ought to say masuk } \\
\text { but he utters masukok. } \\
\text { (3) } \\
\text { The error's happening on } \\
\text { phonetic segment error which } \\
\text { is ought to be announced the } \\
\text { word punya but doubt so that } \\
\text { sound puee. } \\
\text { (4) } \\
\text { The error's happening on } \\
\text { syllable segment error. } \\
\text { Speaker ought to call word } \\
\text { sama but naming see sama } \\
\text { but is cut on syllable, next it } \\
\text { changes meaning. } \\
\text { (2), (3), dan (4) are anticipation } \\
\text { error type. }\end{array}$ \\
\hline 3 & $\begin{array}{l}\text { Musdalifah } \\
1\end{array}$ & $\begin{array}{l}\text { There is one slip of } \\
\text { the tongue: } \\
\text {...dari dulu itu saya } \\
\text { senang nonton } \\
\text { sinen eh } \\
\text { sinetron... }\end{array}$ & $\begin{array}{l}\text { There is error over on } \\
\text { phonology level which } \\
\text { is called word sinen } \\
\text { eh, it should be } \\
\text { sinetron }\end{array}$ & $\begin{array}{l}\text { The error's happening on word } \\
\text { segment error. Speaker ought } \\
\text { to say word sinetron but one } \\
\text { utter word sinen. This is } \\
\text { anticipation error type. }\end{array}$ \\
\hline
\end{tabular}


IJASOS- International E-Journal of Advances in Social Sciences, Vol. III, Issue 7, April 2017

\begin{tabular}{|c|c|c|c|c|}
\hline 4 & $\begin{array}{l}\text { Musdalifa, } \\
\text { Evi, dan } \\
\text { Lolok }\end{array}$ & $\begin{array}{l}\text { There is one slip of } \\
\text { the tongue: } \\
\text {...peralatan } \\
\text { pertama kabel eh } \\
\text { tang untuk } \\
\text { memotong kabel... }\end{array}$ & $\begin{array}{l}\text { There is error over on } \\
\text { word level which is } \\
\text { called word tang it } \\
\text { ought to utter kabel } \\
\text { that is different } \\
\text { meaning. }\end{array}$ & $\begin{array}{l}\text { This is semantic (Freudian } \\
\text { Slips) error type }\end{array}$ \\
\hline 5 & Ipul & $\begin{array}{l}\text {...adegan sinetron, } \\
\text { ada cewek jalan } \\
\text { tabrakan sama } \\
\text { cewek abis itu } \\
\text { kenalan jadian... }\end{array}$ & $\begin{array}{l}\text { There is error over on } \\
\text { word level which is } \\
\text { called word cewek, it } \\
\text { should be cowok that } \\
\text { is different meaning. }\end{array}$ & $\begin{array}{l}\text { This is semantic (Freudian } \\
\text { Slips) error type but speaker } \\
\text { doesn't realise that error. }\end{array}$ \\
\hline 6 & Lolok & $\begin{array}{l}\text { There is one slip of } \\
\text { the tongue: } \\
\text {...ada kutengok } \\
\text { tempat makanan } \\
\text { sepat cepat saji... }\end{array}$ & $\begin{array}{l}\text { There is error over on } \\
\text { word level which is } \\
\text { called word sepat, it } \\
\text { ought to utter cepat } \\
\text { that is different } \\
\text { meaning. }\end{array}$ & $\begin{array}{l}\text { This is semantic (Freudian } \\
\text { Slips) error type but speaker } \\
\text { realises error that and } \\
\text { substitutes word that really } \\
\text { accords to fathom a meaning. }\end{array}$ \\
\hline 7 & $\begin{array}{l}\text { Musdalifah } \\
2\end{array}$ & $\begin{array}{l}\text { There are three } \\
\text { slips of the tonge: } \\
\text { (1) } \\
\text { Kitakan jadi nonton } \\
\text { sinetron tidak bisa } \\
\text { senoi ngak bisa } \\
\text { pindah sinetron } \\
\text { (2) } \\
\text {...dan saya takut } \\
\text { kalau keluarga } \\
\text { saya jadi beran } \\
\text { dan saya takut } \\
\text { keluarga saya jadi } \\
\text { berantakan... } \\
\text { (3) } \\
\text {...dan yang paling } \\
\text { bench dan yang } \\
\text { paling saya benci } \\
\text { itu... }\end{array}$ & $\begin{array}{l}\text { (1) and (2) errors are } \\
\text { happening on word } \\
\text { level. Speaker wants } \\
\text { to say sinetron and } \\
\text { berantakan but } \\
\text { available concept that } \\
\text { shall beforehand pass } \\
\text { on so that word said } \\
\text { null. } \\
\text { The (3) error is on } \\
\text { phonetic level. } \\
\text { Speaker wants to say } \\
\text { benci but she says } \\
\text { bench. }\end{array}$ & $\begin{array}{l}\text { (1), (2), dan (3) } \\
\text { This is anticipation error type. } \\
\text { This comica can repeat } \\
\text { statement if statement in } \\
\text { advance happens error. }\end{array}$ \\
\hline 8 & $\begin{array}{l}\text { Musdalifa } \\
\text { dan Cemen }\end{array}$ & $\begin{array}{l}\text { There are five slips } \\
\text { of the tongue: } \\
\text { 1. Musdalifah } \\
\text { Speech: } \\
\text { (1) } \\
\text { Apa sih kerennya } \\
\text { mas Cemen. Udah } \\
\text { keris... eh kurus... } \\
\text { kecil... } \\
\text { (2) } \\
\text {...dan keluarga } \\
\text { saya itu fanaktik } \\
\text { dangdut, fanatik }\end{array}$ & $\begin{array}{l}\text { (1) } \\
\text { Error is happening on } \\
\text { word level. Speaker } \\
\text { wants to say keris it } \\
\text { ought to utter kurus } \\
\text { that is different } \\
\text { meaning. } \\
(2),(3) \text {, dan (4) errors } \\
\text { are happening on } \\
\text { syllable segment error. } \\
\text { (5) } \\
\text { There is error over on } \\
\text { phonology level which } \\
\text { is called word rakrak, it } \\
\text { should be rakyat }\end{array}$ & $\begin{array}{l}\text { (1) } \\
\text { This is semantic (Freudian } \\
\text { Slips) error type but speaker } \\
\text { realises error that and } \\
\text { substitutes word that really } \\
\text { accords to fathom a meaning. } \\
\text { (2), (3), (4), and (5) are } \\
\text { perseverations error type. }\end{array}$ \\
\hline
\end{tabular}




\begin{tabular}{|c|c|c|c|c|}
\hline & & $\begin{array}{l}\text { dangdut ya. } \\
\text { Terbukti... } \\
\text { (3) } \\
\text { Suatu saat saya } \\
\text { ikut kompetisi ini, } \\
\text { mamak sa bapak } \\
\text { saya request lagu } \\
\text { ini. Eh nanti... } \\
\text { (4) } \\
\text {... saya berpikir, } \\
\text { apa ya, } \\
\text { berberpikiran jadi } \\
\text { biduan... } \\
\text { 2. Cemen Speech: } \\
\text { (5) } \\
\text { Untung dari suara } \\
\text { gendang, bukan } \\
\text { suara rakyat. Kalau } \\
\text { dari suara rakrak } \\
\text { ngak ada yang } \\
\text { dengerin. }\end{array}$ & & \\
\hline 9 & Cemen & $\begin{array}{l}\text { There are two slips } \\
\text { of the Tongue: } \\
\text { (1) } \\
\text { Terutama keluarga } \\
\text { gua. Mama so.. } \\
\text { silakan berdiri... } \\
\text { (2) } \\
\text {...udah kagak ada } \\
\text { makanan dan } \\
\text { minuman khas } \\
\text { bahk.. jah.. jadi... }\end{array}$ & $\begin{array}{l}\text { (1) } \\
\text { There is error over on } \\
\text { phonology level which } \\
\text { is called word so (must } \\
\text { be say si... by context } \\
\text { silahkan) it should be } \\
\text { silahkan } \\
\text { (2) error is happening } \\
\text { on word level. Speaker } \\
\text { wants to say jadi but to } \\
\text { say bahk (bahkan) or } \\
\text { jah-di (jadi). }\end{array}$ & $\begin{array}{l}\text { (1) } \\
\text { This is Perseverations error } \\
\text { type. } \\
\text { (2) } \\
\text { This is semantic (Freudian } \\
\text { Slips) error type because he } \\
\text { wants to say word jadi, in fact, } \\
\text { he says word bahk (bahkan). } \\
\text { But, the error's happening } \\
\text { again concept false after saying } \\
\text { word jah (jadi) and this is } \\
\text { anticipation error type. }\end{array}$ \\
\hline
\end{tabular}

\section{b. Couse of Pause and Slip of the Tongue on Stand-up Comedy Show}

Cause of pause and slip of the tongue which is:

a. Nerves and Headlong

In the show of SUCA, symptom of pause and slip of tongue on comica is caused by the nervousness in the middle of delivering the humorous material. It seems on delivering to be in rush. The nervousness, shyness, and fear are attitudes that influence to someone in talking. If someone feels nervous, what something is in his/ her mind can suddenly be gone. Furthermore, the attitude will make someone tend to talk in rush and stuttering. It will lead to appear the errors in sentence production. The words which are produced in brain do not utter well when the people speak.

b. Spontan (Not Deliberate)

Slip of the tongue can also happen since undeliberateness (spontaneity), so speaker doesn't realise that incorrect voiced one while does not be reminded.

c. Deliberate Creates Humour

Error that intentional can evoke humour effect. it who makes comedians to string up word that error is impressed funny and entertain. 
Pause on SUCA by comica happens since was ready to produce sentence as a whole, forget word who will be uttered, on the quivive in chooses word, nerves, and worrier for fear false. Slip of the tongue on SUCA by comica caused strop by headlong attitude, nerves, intentional wisecrack, are not deliberate, and doesn't concentrate.

It corresponds to research that did by Kawachi (2002) that found a variety of practice effects on speech production planning by comparing slip of the tongue in everyday conversation and those in TV programs. Although this study has also shown that there are some aspects of the speech production planning mechanism that are insusceptible to practice. Most of the content-practice effects can be accounted for by the following four characteristics of content-practice. First, content-practice shifts the locus of errors from the level of lexical selection down to the levels of syntax and phonology and reduces errors involving open-class morpheme, especially predicates. Second, it enables the speaker to plan ahead with less influence from the previously processed elements. These two characteristics can be explained in terms of the fact that less attention is needed for lexical selection of open-class morpheme and monitoring in preplanned speech. Third, because content-practice prevents elements outside of the linguistic context from intruding into the current speech plan, non-contextual lexical substitutions and blends are less likely to occur in preplanned speech. Finally, content-practice increases planning distance with processing using a greater memory capacity.

\section{CONCLUSION}

Generally, the causes of pause and slip of tongue in the show of SUCA by Comica delivering the humour discourse are the obligations in context of timing management and competitive situation. Pause and slip of tongue occur based on psychology factors; they are nervous, spontaneous, on purpose to create the humour. In the show of SUCA, almost the comica realizes when they make something in error and correct them all. Whereas, the error sometimes occurs without realizing. All the errors in language which occur in every level of linguistic are the level of phology, syllable and syntax.

\section{ACKNOWLEDGEMENT}

The researcher expresses the appreciation to the Indonesia Endowment Fund for Education (LPDP) who funds this research. Moreover, the financial education of UPI is also funded by LPDP so that the researcher appreciates to the chance on getting study in this graduate level. My appreciation also goes to the advisers and reviewer all at once, that is Dr. Andoyo Sastromiharjo, M.Pd who gave me guidance and ideas in this study.

\section{REFERENCE LIST}

Aitchison, Jean. 2008. The Articulate Mammal (Fiveth edition). London dan New York: Routledge.

Clark, H.H. and Eve. V.Clark. 1977. Psychology and Language. San Diego: Harcourt Brace Jovanovich Publishers.

Dardjowidjojo, Soenjono. 2008. Psikolinguistik: Pengantar Pemahaman Bahasa Manusia. Jakarta: Yayasan Obor Indonesia.

Field, Jhon. 2004. Psycolinguistics: They Key Concepts. London: Routledge.

Gary S. Dell and Jill A. Warker. The tongue slips into (recently learned) patterns University of Illinois at Urbana-Champaign

Gleason, Jean, Berko dan Ratner, Nan, Bernstein, ed. 1998. Psycholinguistics, New York: Harcourt Brace College Publishers

Jeager. Jeri G. 2005. Kid's Slips: What Young Children's Slip of the Tongue, Reveal about Language Development. New Jersey: Lawrence Erlbaum.

Kawachi, Kazuhiro. 2002. Practice Effects on Speech Production Planning: Evidence from Slips of the Tongue in Spontaneous vs. Preplanned Speech in Japanese (Journal) Journal of Psycholinguistic Research, Vol. 31, No. 4, July 2002, 363-390.

Mayasari, Ira. 2015. Senyapan dan Kilir Lidah dalam Produksi Ujaran (Kajian Psikolinguistik), Deiksis: Jurnal Ilmiah Bahasa dan Seni, Vol. 07 No.02, Mei 2015: 79-170.

Yus, Anita. 2012. Aspeech Error/ Tongoe Slips on Early Age Term (Journal). Linguistics and Art study, Vol. 24, No. 1, Juni 2012: 1-10. 